History Society and Manchester Geological Society, as well as a small typical collection originally belonging to the College and the complete mineralogical and metallurgical collections of the late David Forbes; the series are admirably arranged for the purposes of study. Prof. Boyd Dewkins is curator.

\section{A REAL TELEGRAPH}

A NEW invention of a real practical chaA racter, not a mere "paulo post futurum" invention like many we have heard of lately, has just been made by Mr. E. A. Cowper, the well-known mechanical engineer. It is a real telegraphic writing machine. The writer in London moves his pen, and simultaneously at Brighton another pen is moved, as though by a phantom hand, in precisely similar curves and motions. The writer writes in London, the ink marks in Brighton. We have seen this instrument at work, and its marvels are quite as startling as those of the telephone. The pen at the receiving end has all the appearance of being guided by a spirit hand. The apparatus is shortly to be made public before the Society of Telegraph Engineers. We give a facsimile of the writing produced by this telegraphic writing machine.

\section{GEOGRAPHICAL NOTES}

THE Spanish Ministry of Public Instruction has just issued a very important publication, being a collection of letters of Christopher Columbus, and of his contemporaries, as well as of reports sent in, during the sixteenth century by governors of the new American provinces, the originals of these letters and reports being now in the State Archives of Spain. The work, which bears the title "Cartas de India" (Letters from India), and forms a large volume of 877 folio pages, contains the following highly interesting documents: (I) Two autograph letters from $\mathrm{Co}$ lumbus, written in 1502 to King Ferdinand and Queen Isabella, the first letter dwelling upon the necessity of measures for increasing the population of the island "Española" (San Domingo), and the second being a discussion on the art of navigation; (2) a letter from Amerigo Vespuchi to the Cardinal Gimenes di Cuneros, Archbishop of Toledo, dated Sevilla, 1508, and dealing with the merchandise to be sent to the Antilles; (3) two letters from Fra Bartholomeo de las Casas, Archbishop of Nicaragua, to the Infanta Don Filippo, dated Gracias a Dios, in Guatcmala ; (4) two letters from. Bernaldo Diaz del Castillo, one of the warriors of the small army of Cortes, and author of a history of Mexico, to Charles the Fifth (1552), and to Philip the Second (1558); (5) letters from the baccalaureates Don Pedro de Gasca and Don Christophor Vaca de Castro, dated Quito, I54I and Cusco (1542), announcing to Charles the Fifth the death of the Marchese Don Pizaro and the insurrection of Don Diego de Almagro; both letters are very interesting, being accounts of eye-witnesses; (6) a very interesting letter of Donna Isabella Quivara to the Regent, Donna Huana, about the remark-

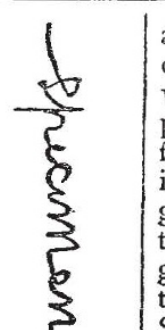

able courage displayed by women during the expedition of Cortes, when all male members of the expedition. were exhausted by disease. The work contains 652 pages of text and 225 pages of appendix, in which we find twenty-nine autograph letters and reports of various important historical persons ; twenty-one sheets of autographs of Columbus, Vespuchi, Las Casas, Diaz del Castillo, Gimenez, \&c. ; a map of the fortifications where the gems of the Incas were found; and maps of Australia, of the River Amazon, the Antilles Archipelago, and Magellan Strait, drawn in the sixteenth century. We are sure that all friends of historical geography will feel grateful to the Spanish Government for this valuable publication.

Col. PRJVAlsky has left St. Petersburg to make anothex trip in Central Asia. He will proceed by Orenburg, Omsk, and Semipalatinsk to the Chinese frontier, thence to Hami, Hansu and Lassa. From Lassa he intends to. reach the Himalaya by the Brahmapootra. Returning. then to Lassa, he will visit Khotan, Kashgar, and cross. the intervening plateaux to Russian Khokand. The journey is to occupy two years.

PÈre HORNER has addressed a letter, dated Zanzibar, December 12, to Les Missions Catholiques, announcing that the members of the German scientific expedition have returned in bad health. This expedition, under the command of Herr C. Denhardt, started from Melinda, and explored the course of the River Dana, which has hitherto been supposed to take its rise in the slopes of Mount Kenia. They experienced many difficulties, and did not succeed in getting more than about sixty miles into the interior. According to Père Horner's report, in the place of Mount Kenia, covered with snow, they found only plains, and though they questioned more than 200 persons on the subject, they could find no one who had heard of the mountain. Père Horner thinks that the German travellers have not been far enough into the interior, and he says that they are going back again shortly to solve the problem. The truth, however, we believe is that Herr Denhardt has found that the Dana has. a widely different course from that generally assigned to. it, and that it does not flow anywhere near Mount.Kenia. The party obtained a very complete series of meteorological observations, and they report that at some distance from the coast they met with a quiet and industrious tribe called the Vakopomo, who, it is thought, would welcome missionaries among them, if the fanatic Somalis of the coast region would allow them to pass.

In the February number of the Geographical Society's new periodical we find a curious and learned paper by Sir Henry Rawlinson, entitled "Rough Notes on Prehistoric Cyprus, and another on the "Upper Basin of the Kabul River," from Mr. Markham's versatile pen, accompanied by a carefully drawn map of the Hindu Kush. Some of the geographical notes are of considerable interest. A St. Petersburg correspondent reports finding Prjvalsky restored to his habitual vigorous state of health and busy preparing for his next expedition, in which he hopes to reach Lhassa by the Hami and Sha-chau road, accompanied by young Eklon. Prjvalsky's Lob-Nor plantcollection turns out to be not very rich, the number of species being exceedingly few. Under the beading "Explorations North of India," we have the leading features of an unpublished report by Capt. Woodthorpe, R.E., and Lieut. Harman, of their recent work in the unexplored Miri and Mishmi Hills. In the latter region Capt. Woodthorpe obtained a fairly accurate knowledge of the sources of the Dihong River and the course of its main stream in the bills. The result of these explorations proves that the volum of the Subansiri is only one-fourth of that of the Dihong, which tends more than ever to identify the latter with the great river of Thibet. Some particulars are also furnished respecting the Dar-es-Salaam road in East Africa. 